\title{
A REVIEW ON THE DEVELOPMENT OF PALM OIL MILL EFFLUENT (POME) FINAL DISCHARGE POLISHING TREATMENTS
}

\author{
NAHRUL HAYAWIN ZAINAL*; NOR FAIZAH JALANI*; ROPANDI MAMAT* and ASTIMAR, A A*
}

\begin{abstract}
Raw palm oil mill effluent (POME) contains high amount of organic materials and residual oil that will impose high biological oxygen demand (BOD) and chemical oxygen demand (COD). It has a high acidic value, high total suspended solids (TSS) and is dark brownish in colour. Raw POME is a highly polluting wastewater and as such, it cannot be freely and/or directly discharged into any source of water or river without prior proper treatment. The treatment of raw POME is an important issue in palm oil mills and the method of treatment has attracted many researchers and non-governmental organisation (NGO) associated with environmental pollution. Owing to the more stringent effluent environmental regulations by the Department of Environment (DOE) Malaysia, research interest has recently shifted to the development of sustainable effluent polishing technologies. Therefore, it is perhaps worthwhile to look into a new viable and sustainable technology such as utilisation of renewable oil palm biomass as bio-adsorbents. This article reviews the development of polishing treatments for POME final discharge and further discusses the application of palm-based activated carbon for the treatment system. In conclusion, the integration system of conventional POME treatment with bio-adsorbents could be considered as a sustainable approach, thus solving environmental problems of waste disposal and pollution control for the oil palm industry.
\end{abstract}

Keywords: palm oil mill effluent, oil palm biomass, activated carbon, bio-adsorbents, sustainable.

Date received: 13 October 2017; Sent for revision: 16 October 2017; Received in final form: 14 November 2017 ; Accepted: 14 November 2017

\section{INTRODUCTION}

Oil palm, scientifically known as Elaeis guineensis is one of the potential sources of biomass. The oil palm originates from West Africa and expanded to South-east Asia. Among other crops, oil palm is considered as one of the earliest commercial commodities. The first commercial cultivation area established in Malaysia was in 1917 at Tennamaran Estate, Selangor. Crude palm oil (CPO), produced from oil palm, has become an important commodity

Malaysian Palm Oil Board,

6 Persiaran Institusi, Bandar Baru Bangi,

43000 Kajang, Selangor, Malaysia.

E-mail: nahrul.hayawin@mpob.gov.my in the world, mainly dominated by Indonesia and Malaysia in terms of its production and exportation. Malaysia contributes about $30 \%$ of production and $37 \%$ of world exports contributing to the growth of gross domestic product (GDP) (Kushairi, 2017).

Apart from producing palm oil, the oil palm industry also generating abundant renewable and potential sources of oil palm biomass (OPB). The oil only contributes about $10 \%$ of the total dry matter of the palms; the remaining $90 \%$ being oil palm biomass (Loh and Choo, 2013). About 80 million tonnes of OPB has been generated in 2010 but it is expected to increase to 100 million tonnes in year 2020 (National Innovation Agency of Malaysia, 2013). The OPB includes empty fruit bunch (EFB), oil palm trunk (OPT), oil palm frond (OPF), oil palm 
kernel shell (OPKS), and mesocarp fibre, which are not fully utilised as a renewable source (Theo et al., 2017).

Raw POME, another valuable biomass source, is a thick, brownish liquid effluent comprising of large amounts of solids and high organic contents with indirect potentials to pollute the environment, particularly the waterways and the atmosphere. During milling process, substantial amount of water is consumed for processing, thus generating large volume of raw POME amounting to 43.29 million cubic metres per year based on calculation from 2.5 $\mathrm{m}^{3}$ raw POME generated (MPOB, 2016). According to $\mathrm{Wu}$ et al. (2009), about 5 to $7.5 \mathrm{t}$ of water would be required to process $1 \mathrm{t}$ of $\mathrm{CPO}$ and the remaining $50 \%$ of this water would end up as wastewater effluent. Raw POME is an acidic effluent with very low $\mathrm{pH}$ ranging between 3.5 and 4.2, high chemical oxygen demand (COD), biological oxygen demand (BOD), and total suspended solid (TSS) of 51000 mg litre ${ }^{-1}, 25000 \mathrm{mg}$ litre $^{-1}$ and $18000 \mathrm{mg}$ litre $^{-1}$, respectively (Alhaji et al., 2016; Bello et al., 2013; Hossain et al., 2016; Saeed et al., 2016). Due to the pollution potential of palm oil mill effluent (POME) final discharge and the failure of many industries to comply with the discharge standard, the Malaysian Department of Environment (DOE) is proposing more stringent regulations (Bello and Abdul Raman, 2017). Recently, the DOE made the move to reduce the BOD discharge limit from $100 \mathrm{mg}$ litre $^{-1}$ down to $50 \mathrm{mg}$ litre $^{-1}$ and $20 \mathrm{mg} \mathrm{litre}^{-1}$, depending on the palm oil mill location (Julaidi, 2014; Tabassum et al., 2015). Thus, stringent regulations may continue to evolve as the government and public intensify efforts towards environmental protection and sustainability. Hence, in the next few years, more efforts will be seen towards developing effective polishing technologies for POME final discharge. A wide range of approaches for the treatment of POME have been developed to alleviate the pollution problems caused by the palm oil industry. Previously, open ponding system was the popular choice by the Malaysian palm oil mills for POME treatment systems. The system generally consists of cooling and mixing, anaerobic, facultative and aerobic ponds (Chin et al., 2013; Nurliyana et al., 2015; Vijayaraghava et al., 2007). This ponding system requires long hydraulic retention time (HRT) and large land space and POME final discharge commonly fails to meet the discharge limits set by the Malaysian DOE. Accordingly, the main objective of this review paper is to provide an overview of the prevailing polishing technologies and emphasise on application of activated carbon as bio-adsorption from OPB as potential sustainable technologies. Bioadsorption technique is considered better because of its convenience, ease of operation and simplicity of design (Ahmed and Theydan, 2014). The present review includes preparation of activated carbons from OPB and the use of prepared activated carbons for adsorptive removal of organic and inorganic pollutants of POME final discharge.

\section{PHYSICAL AND CHEMICAL CHARACTERISTICS OF POME}

The average physical and chemical characteristics of raw POME and POME final discharge from a palm oil mills in Malaysia are described in Table 1. It is shown that the level of one of the important parameters, $\mathrm{BOD}$, in POME final discharge is much higher than the current standard discharge limit set by the Malaysian DOE. The colour of POME final discharge, caused by decomposition of lignocellulosicmaterials (Tanetal., 2014), is obviously high and has to decrease to 500 ADMI (American Dye Manufacturers Institutes) for compliance (Bello and Abdul Raman, 2017). High value of colour intensity was caused by the presence of lignin, tannin, humic acids, carotene and other organic matter which are recalcitrant to the conventional treatments. Besides aesthetic problem, colour also affects sunlight penetration and limits potential wastewater reuse. Residual oil is another source of concern, as many industries discharge POME with oil above the discharge limit (Shavandi et al., 2012). Additionally, more stringent regulations for future standard discharge limit must be complied by local palm oil mills as shown in Table 1. The discharge of POME with those levels of concentration would be harmful to the environment. Therefore, alternative methods and technologies such as tertiary treatments on sustainable technologies are needed to treat the POME final discharge before it is safely discharged into the river or other source of water, and those technologies must be able to effectively reduce the pollutant concentrations below the standard limits set by the Malaysian DOE.

\section{CONVENTIONAL TECHNOLOGY FOR POME TREATMENT}

As the article highlights on POME polishing treatment, conventional effluent treatment systems implemented by local palm oil millers are briefly described here. The major types of conventional effluent treatments that are implemented by palm oil millers include ponding systems, membrane filtration and coagulation-flocculation method.

\section{Ponding Systems}

According to Julaidi (2014), there are about 267 mills from a total of 442 palm oil mills that have been given the authorisation to safely discharge the wastewater effluent into inland watercourse. 
TABLE 1. CHARACTERISTICS OF RAW POME AND POME FINAL DISCHARGE WITH THEIR RESPECTIVE STANDARD DISCHARGE LIMITS SET BY MALAYSIAN DEPARTMENT OF ENVIRONMENT AND COMPARISON WITH OTHER STUDIES

\begin{tabular}{|c|c|c|c|c|}
\hline Parameters & $\begin{array}{l}\text { Average value } \\
\text { concentration } \\
\text { (Raw POME) }\end{array}$ & $\begin{array}{c}\text { Average value } \\
\text { concentration } \\
\text { (POME final discharge) }\end{array}$ & $\begin{array}{l}\text { Current standard } \\
\text { discharge limit, } \\
\text { (DOE, 1982) }\end{array}$ & $\begin{array}{l}\text { Future standard } \\
\text { discharge limit, } \\
\text { (DOE, 2015) }\end{array}$ \\
\hline COD (mg litre $\left.{ }^{-1}\right)$ & 51000 & 800 & 100 & NA \\
\hline $\mathrm{BOD}_{3}\left(\mathrm{mg}\right.$ litre $\left.^{-1}\right)$ & 25000 & 200 & 100 & 20 \\
\hline $\mathrm{pH}$ & 9.0 & 4.2 & $5.0-9.0$ & $5.0-9.0$ \\
\hline Temperature $\left({ }^{\circ} \mathrm{C}\right)$ & 85 & 25 & 45 & 45 \\
\hline Colour (ADMI) & 10000 & 500 & 200 & 100 \\
\hline Total suspended solids, (mg litre $\left.{ }^{-1}\right)$ & 18000 & 130 & 400 & 200 \\
\hline Total nitrogen, (mg litre ${ }^{-1}$ ) & 750 & 127 & 200 & 150 \\
\hline Ammoniacal nitrogen, $\left(\mathrm{mg}\right.$ litre $\left.^{-1}\right)$ & 35 & - & NA & NA \\
\hline Total volatile solids, (mg litre $\left.{ }^{-1}\right)$ & 34000 & - & NA & NA \\
\hline Oil and grease, (mg litre $\left.{ }^{-1}\right)$ & $4000-6000$ & - & 50 & 5 \\
\hline Manganese, (mg litre ${ }^{-1}$ ) & 2.0 & - & 10 & 10 \\
\hline Zinc, (mg litre $\left.{ }^{-1}\right)$ & 2.3 & - & 10 & 10 \\
\hline Copper, (mg litre $\left.{ }^{-1}\right)$ & $0.8-0.9$ & - & 10 & 10 \\
\hline Iron, $\left(\mathrm{mg}\right.$ litre $\left.^{-1}\right)$ & 46.5 & - & 50 & 50 \\
\hline Phosphorus, (mg litre ${ }^{-1}$ ) & 180 & - & NA & NA \\
\hline Potassium, (mg litre $\left.{ }^{-1}\right)$ & 2270 & - & NA & NA \\
\hline Magnesium, (mg litre $\left.{ }^{-1}\right)$ & 615 & - & NA & NA \\
\hline Boron, (mg litre $\left.{ }^{-1}\right)$ & 7.6 & - & NA & NA \\
\hline Calcium, (mg litre $\left.{ }^{-1}\right)$ & 439 & - & NA & NA \\
\hline Chromium, (mg litre $\left.{ }^{-1}\right)$ & 10.2 & - & NA & NA \\
\hline
\end{tabular}

Notes: BOD - biological oxygen demand. COD - chemical oxygen demand. NA - not available. ADMI - American Dye Manufacturers Institute. POME - palm oil mill effluent.

Source: Alhaji et al. (2016), Bello et al. (2013), Hossain et al. (2016), Saeed et al. (2016).

The authorisations are based on the location of the mill, preference and land availability to cater for the wastewater treatment plant (Ma, 1999). Open ponding system is adopted by more than $85 \%$ of the mills in Malaysia where POME is discharged into inland water course. This is due to it being inexpensive, low capital, simplicity and ease of handling (Liew et al., 2015). Conventional ponding systems generally consist of cooling and mixing, anaerobic, facultative and aerobic ponds (Figure 1). Cooling and mixing pond serves to stabilise the POME temperature and $\mathrm{pH}$ prior to the anaerobic digestion. Anaerobic stage produces methane gas which is a value-added product for biogas. Facultative and aerobic ponds are necessary to further reduce the organic content in the wastewater before it is discharged to rivers Open ponding system has been proven to successfully reduce the concentration of pollutants such as COD (100 - $1725 \mathrm{mg}$ litre $\left.^{-1}\right)$, BOD (100 - $610 \mathrm{mg}$ litre $\left.^{-1}\right)$ and ammoniacal nitrogen (100 - $200 \mathrm{mg}$ litre $^{-1}$ ) (Chin et al., 1996; Zahrim et al., 2014). However, the discharged effluents from several palm oil mills often do not fulfill the regulatory discharge limits, especially on the insignificant removal of lignin-tannin (Bello et al., 2014; Zahrim et al., 2014). Unremoved lignin will affect the colour of POME while posing risk to the environment due to the interactive nature of the lignin with biological treatment (Bello and Raman, 2017). This system also requires long total HRT between 45 - 60 days and large land area (Othman et al., 2014; Ma, 1999). Nevertheless, more efforts are being promoted by the government to develop additional treatment method such as the polishing technology to produce wastewater effluents that conform to the regulatory discharge limits (Taha and Ibrahim, 2014). The last few years have seen a major shift towards sustainability, from conventional treatments of POME to tertiary treatments using various technologies such as membrane filtration (Amat et al., 2015), coagulation-flocculation (Poh et al., 2014) and adsorption (Bello et al., 2014; 2013; Mohammed and Fong, 2014).

\section{Membrane Filtration}

Worldwide, membrane technologies have received great attention and are commonly used in water and wastewater treatments due to their efficiency in eliminating pollutants from wastewater streams. Membrane technologies have numerous advantages such as high removal rate, stable effluent quality, modularity, free chemical addition, and capability for integration with other wastewater treatment systems (Taheran et al., 2016). For POME polishing treatments, membrane technologies have been used to reduce the concentration of COD, BOD, TSS, colour and any organic elements (Table 2). Recently, many studies used membrane such as nanofiltration (NF), ultrafiltration (UF) and reverse 


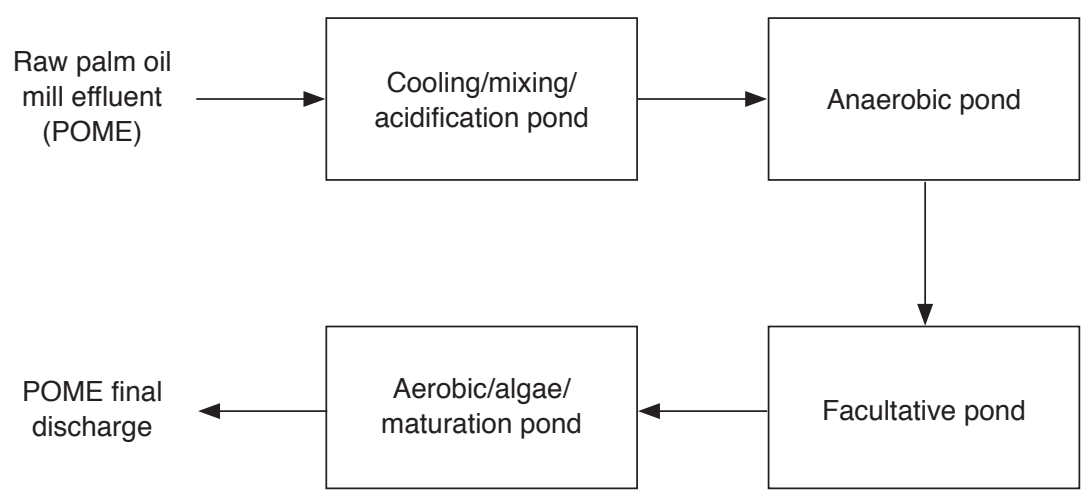

Figure 1. Typical configuration for ponding treatment system of palm oil mill effluent (POME).

osmosis (RO) to increase the efficiency of removal of pollutants (Ganiyu et al., 2015; Jegatheesan et al., 2016; Taheran et al., 2016). However, many studies found that membrane technology is ineffective in reducing the colour concentration of POME after the conventional ponding system, as shown in Table 2. According to Idris et al. (2010), pre-treatment of POME before tertiary treatment using membrane is used will result in higher permeate quality in terms of COD, BOD, TSS, and colour. Another study by Ahmad et al. (2006a) is the application of coagulation method with membrane filtration for the production of drinking water from POME wastewater. The study has successfully removed more than $99 \%$ of COD, TDS and nitrogen, with a $100 \%$ removal of colour, turbidity, oil, and grease. The clear water produced was satisfactory as it meets the standard requirement for drinking water. Some researchers have investigated the removal of residual pollutants from POME final discharge using a membrane bioreactor (MBR). MBR is a hybrid system employing two interdependent treatment processes; biological process and membrane filtration (Jegatheesan et al., 2016). A major drawback of MBR is the long HRT (Taha and Ibrahim, 2014). Recently, Ahmed et al. (2015) have proposed an integrated treatment process for POME final discharge based on biological treatment and membrane filtration to achieve energy production and high quality effluent. The process consists of biological treatment using an up-flow anaerobic sludge-fixed film reactor, followed by membrane separation using UF and RO. However, the major drawback when using membrane technology is pore blocking at the surface of the membrane, therefore, affecting the maintenance and capital cost (Said et al., 2015).

\section{Coagulation-flocculation Method}

Another technology attempted for tertiary treatment of POME final discharge was coagulation- flocculation method. Coagulation-flocculation is commonly used as an enhancement for tertiary treatment of POME final discharge by removing colour, suspended solids and organic matter from wastewater. It implicates the use of chemical agents to assist flocculating, sedimentation and elimination of dissolved and suspended solids from wastewater. The coagulant basically uses chemicals from aluminum and iron-based compounds, as they are simple, easy to handle, cheap, and have good removal efficiency towards the wastewater intended (Keeley et al., 2014). However, the residual aluminium and iron concentrations have the possibility to inhibit the biological treatment process in wastewater such as reduction of microorganism respiration rate and low organic matter elimination (Lees et al., 2001). Recently, interests have been shifted to natural and biodegradable coagulants such as cotton (Nourani et al., 2016), chitosan (Ang et al., 2016), natural seed gum (Shak and Wu, 2014), Jatropha curcas seeds, and Moringa oleifera (Bhatia et al., 2007). This is because chemical coagulants are non-biodegradable, costly and not environmental-friendly. Several researchers have reported that the treatment of POME final discharge using chemical and natural coagulants as well as a new series of process including coagulation, sedimentation, solvent extraction, membrane filtration and adsorption are much more effective and convenient for removal of pollutants than using the existing systems (Table 3) (Ahmad et al., 2003b).

\section{CURRENT TREND AND FUTURE PERSPECTIVES}

In recent years, the palm oil millers have displayed interest to implemert more sustainable and emerging technologies in their mills such as biogas capture and/or composting technology as well as going towards zero-waste approach. The aims of those systems are to reduce the greenhouse gas emissions (GHG) and eliminating pollutants that are 
TABLE 2. MEMBRANE TECHNOLOGIES FOR POME POLISHING TREATMENTS

\begin{tabular}{|c|c|c|c|c|c|c|c|}
\hline $\begin{array}{l}\text { Types of } \\
\text { membrane }\end{array}$ & $\begin{array}{c}\text { Treatment } \\
\text { time (hr) }\end{array}$ & $\mathrm{pH}$ & $\begin{array}{c}\text { BOD removal } \\
(\%)\end{array}$ & $\begin{array}{c}\text { COD removal } \\
(\%)\end{array}$ & $\begin{array}{c}\text { Colour removal } \\
(\%)\end{array}$ & $\begin{array}{c}\text { TSS removal } \\
(\%)\end{array}$ & References \\
\hline Membrane UF + RO & 4 & 7 & 99.4 & 98.8 & - & 100 & $\begin{array}{l}\text { Ahmad et al. } \\
\qquad(2003 a)\end{array}$ \\
\hline Membrane UF + NF & 4 & - & - & - & 97.9 & - & $\begin{array}{l}\text { Amat et al. } \\
\text { (2015) }\end{array}$ \\
\hline Membrane UF & 4 & 9 & - & 88 & - & 80 & $\begin{array}{l}\text { Said et al. } \\
\text { (2015) }\end{array}$ \\
\hline Membrane UF & 1.5 & 8 & 90 & 90 & - & - & $\begin{array}{c}\text { Azmi and Yunos } \\
\text { (2014) }\end{array}$ \\
\hline Membrane UF & - & 7 & - & 95 & - & 79 & $\begin{array}{l}\text { Azmi et al. } \\
\text { (2012) }\end{array}$ \\
\hline Membrane UF & 4.5 & - & - & 57 & - & 97.7 & $\begin{array}{l}\text { Wu et al. } \\
\quad(201\end{array}$ \\
\hline
\end{tabular}

Note: BOD - biological oxygen demand. COD - chemical oxygen demand. NF- nanofiltration. UF- ultra-filtration. RO - reverse osmosis. POME - palm oil mill effluent.

TABLE 3. APPLICATION OF COAGULATION-FLOCCULATION IN POME POLISHING TREATMENT

\begin{tabular}{|c|c|c|c|c|c|c|c|}
\hline $\begin{array}{c}\text { Type of coagulant- } \\
\text { flocculant }\end{array}$ & $\begin{array}{l}\text { Dosage } \\
\left(\text { g litre }^{-1}\right)\end{array}$ & $\mathrm{pH}$ & $\begin{array}{l}\text { Mixing rate } \\
\quad(\text { rpm) }\end{array}$ & $\begin{array}{l}\text { Time } \\
(\min )\end{array}$ & $\begin{array}{c}\text { COD removal } \\
(\%)\end{array}$ & $\begin{array}{c}\text { TSS removal } \\
(\%)\end{array}$ & Reference \\
\hline $\begin{array}{l}\text { Polialuminum } \\
\text { chloride (PAC) }\end{array}$ & $1-3$ & - & 80 & 180 & 70 & - & $\begin{array}{c}\text { Nasrullah et al. } \\
\text { (2017) }\end{array}$ \\
\hline $\begin{array}{l}\text { Calcium lactate- } \\
\text { polyacrylamide }\end{array}$ & 0.5 & - & 258 & 23 & 58 & 58 & $\begin{array}{l}\text { Zahrim et al. } \\
\qquad(2014)\end{array}$ \\
\hline Chitosan & 0.5 & 4 & 100 & 15 & 95 & - & $\begin{array}{l}\text { Ahmad et al. } \\
\qquad(2006 \mathrm{c})\end{array}$ \\
\hline Alum & 2.12 & 6 & - & 20 & 59 & - & $\begin{array}{c}\text { Malakahmad and } \\
\text { Chuan (2013) }\end{array}$ \\
\hline Mango pit & 50 & 4 & 200 & 60 & 89 & 96 & $\begin{array}{c}\text { Asadullah and } \\
\text { Rathnasiri (2015) }\end{array}$ \\
\hline
\end{tabular}

Notes: COD - chemical oxygen demand. TSS - total suspended solids. POME - palm oil mill effluent.

being released to the environment. Incorporating biogas system in POME treatment helps to reduce the BOD between $50 \mathrm{mg}_{\text {litre }}^{-1}$ and $100 \mathrm{mg}$ litre $^{-1}$, and COD between $1400 \mathrm{mg}$ litre ${ }^{-1}$ and $12000 \mathrm{mg}$ litre $^{-1}$ (Loh et al., 2017). As for composting technologies, the biomass produced from palm oil, specifically empty fruit bunch (EFB), has high nutrient value among other oil palm biomass. Several attempts have been made to utilise POME final discharge in composting such as through vermicomposting and co-composting with EFB (Adam et al., 2016; Nahrul Hayawin et al., 2014; 2016a; Nurliyana et al., 2015). However, there are many issues that need to be addressed such as heavy metals content in POME, selection of effective microbes as well as leachate management. These issues can take the mills back to where it started, meaning that they would need to invest more for additional treatment system prior or after the composting system. Both technologies are capable of generating more income for the industry and can occasionally help reduce the organic loading of POME. In Malaysia, the implementation of biogas capturing is one of the activities in Economic Transformation Programme (ETP) under the Palm Oil National Key Economic Area (NKEA), where it targets to increase the gross national income (GNI) by year 2020 (MPOB, 2017). The GHG emission reduction can be attained through methane avoidance from open ponding system and composting as well as avoiding fossil fuel consumption needed to generate electricity and chemical fertilisers (Krishnan et al., 2017). Furthermore, through Clean Development Mechanism (CDM) programme, reduction of the GHG can be sold as carbon credits and become additional revenue to the mills (Yoshizaki et al., 2012). Biogas and composting can be integrated in zero-waste approach technology for the palm oil mills. This approach aims to abolish the palm oil mill waste from being discharged to the environment (i.e. watercourse and land). The reclaimed water from the system can be recycled as processed water in palm oil mill or as a boiler feed water (Ahmad et al., 2003a; Loh et al., 2013; Tabassum et al., 2015). 
Nonetheless, effective tertiary or polishing treatment is still required to ensure more holistic treatment for producing a POME final discharge that can consistently meet the DOE standard effluent discharge limit and satisfy public perception. For zero-waste approach, effective POME treatment technology is not less important prior to the water reclamation process.

Among the new and emerging wastewater treatment, adsorption technique shows high potential to be incorporated in POME polishing for effective treatment system. The advantages of adsorption system are due to the simple design and process, low capital cost and small footprint relative to other polishing system (Rashed, 2013). Adsorbent can be derived from natural source such as clay, coal, mineral clays, zeolite, etc. Besides natural sources, bio-adsorbent can also be produced from agricultural waste such as banana peel (Mohammed and Fong, 2014), coconut shell (Babel and Kurniawan, 2004), bamboo (Evbuomwan et al., 2012) rice husk, and saw dust (Malik, 2003). OPB that is readily available in the mills seems suitable to be exploited as a precursor for bio-adsorbent production. Conventionally, OPB are applied for mulching, composting and as fuel for boiler co-firing (Bachmann and Loh, 2013). Presently, the commercial utilisation of OPB is moving towards high-value product formation (Chin, 2016). However, the main challenge to materialise the commercial scale production is the supply chain of raw materials, for which the biomass sources that are mostly located in remote areas can incur high transportation cost. The conversion of OPB to bio-adsorbent in the form of activated carbon (AC) for POME final discharge polishing treatment is likely to be sustainable. The raw materials are readily available in mills so the raw material and transportation cost are excluded in the bio-adsorbent production cost. Instead of using commercial adsorbent for the adsorption treatment, the operating cost of POME final discharged polishing plant can also be reduced when mills utilise their own homemade bio-adsorbent.

\section{OPB as Bio-adsorbent}

Bio-adsorbent is produced by first converting the biomass to biochar to increase the carbon content. Biochar from EFB, OPKS and mesocarp fibre can be formed through conventional carbonisation (Rugayah et al., 2014; Siti Hadjar et al., 2012), microwave carbonisation (Foo and Hameed, 2011a; Ibrahim et al., 2017; Nahrul Hayawin et al., 2016b), self-sustained carbonisation (Nahrul Hayawin et al., 2016c), and pyrolysis (Amosa, 2015; Nur Sulihatimarsyila et al., 2017). Different carbonisation method with different heating profile will affect the biochar characteristics and yield. During this process, the fixed carbon content of the biomass increases as the chemical composition is changed by the release of moisture and most of the volatile components. The lignocellulosic components (i.e. cellulose, hemicellulose and lignin) also decompose during these processes (Nahrul Hayawin et al., 2016a). The surface area for biochar usually ranges between 200 and $350 \mathrm{~m}^{2} \mathrm{~g}^{-1}$ depending on the raw materials used (Foo and Hameed, 2011b; Nur Sulihatimarsyila et al., 2017).

Biochar is then activated to remove the remaining organic residue thus increasing its porosity and surface area so that it can effectively function as a bio-adsorbent. Porous surface area is crucial for the adsorption process in order to trap organic molecules and other impurities from the solution (Othman et al., 2014). OPKS and EFB biochar can be activated through physical or chemical method, or a combination of both. Physical activation, also known as thermal activation, is conducted at high temperature in the range of $800^{\circ} \mathrm{C}$ to $1000^{\circ} \mathrm{C}$, depending on raw materials using steam, carbon dioxide $\left(\mathrm{CO}_{2}\right)$, nitrogen $\left(\mathrm{N}_{2}\right)$ or their mixtures as an oxidising and fluidising agent (Guo et al., 2008; Nur Sulihatimarsyila et al., 2017; Rugayah et al., 2014; Wan Daud et al., 2000). Chemical activation of EFB and OPKS can also be conducted using various chemicals as a dehydrating agent such as potassium hydroxide $(\mathrm{KOH})$, phosphoric acid $\left(\mathrm{H}_{3} \mathrm{PO}_{4}\right)$ and sulphuric acid $\left(\mathrm{H}_{2} \mathrm{SO}_{4}\right.$ ) (Foo and Hameed, 2011b; Joseph et al., 2009). As compared to thermal activation, the advantage of chemical activation process is that it is conducted at low temperatures and the chemical will also enhance the decomposition of the lignocellulosic materials as well as eliminating the organic residues, hence, providing higher porosity and surface area (Rafatullah et al., 2013). Meanwhile, the disadvantage is that a large volume of chemical is needed with proper chemical waste treatment and this could lead to environmental issues as well as incurring high operating cost.

The activated carbon is acknowledged as a promising adsorbent to be applied in various applications due to its low cost, well-developed pore structures, and high adsorption capacity. At present, the increasing abundance of OPB wastes has resulted in various environmental problems. Accordingly, these agro wastes can be employed as potential low-cost precursors for the activated carbon production.

\section{Integrated Polishing Treatments Using Bio-adsorbent for POME Treatment}

Recently, the research interest seems to have shifted to the development of sustainable polishing technologies. Therefore, it is worthwhile to look into a new viable and sustainable technology by utilising the renewable OPB as bio-adsorbents. The palm oil industry's vision to have sustainable 
milling process can be achieved by converting the 'waste' (EFB and OPKS) to 'wealth' product and utilising it for the environmental abatement processes. Previous studies proved that palm-based bio-adsorbents have great potential to remove residual organic pollutants, heavy metals and colour from POME by incorporating the tertiary treatment in final polishing step (Table 4). The bioadsorbent is commonly applied and integrated with ponding system or existing polishing system, such as membrane filtration and coagulation-flocculation treatment (Figure 2). Few studies demonstrated the integrated treatment system of POME final discharge from the ponding system with palmbased bio-adsorbent. The treatment carried out by mixing the POME final discharge with bioadsorbent at pre-determined dosage (in the range of 0.5 to $300 \mathrm{~g} \mathrm{litre}^{-1}$ ), mixing rate (in the range of $20-150 \mathrm{rpm}$ ) and adsorption treatment time (0.5 to $24 \mathrm{hr}$ ) in batch treatment system. For these methods, the bio-adsorbent is able to reduce BOD, COD and colour in POME final discharge up to $88 \%, 98 \%$ and 100\% respectively (Ibrahim et al., 2017; Mohammed, 2013; Nur Sulihatimarsyila et al., 2017; Rugayah et al., 2014).

However, batch treatment system seems less practical for commercial mills due to relatively longer HRT (12 - 24 hr). Through continuous system, OPKS-AC (oil palm kernel shell activated carbon) adsorption treatment on POME final discharge of polishing system resulted in higher pollutant removal compared with the adsorption treatment of POME from the ponding system. The maximum colour and COD reduction of POME final discharge were $98 \%$ and $81 \%$, respectively (Nor Faizah et al., 2016). Continuous adsorption in fixed bed column can also help in reducing the HRT to as low as $30 \mathrm{~min}$, but the bio-adsorbent needs to be replaced or regenerated once saturated. The performance of continuous adsorption in fixed bed configuration is affected by flow rate, residence time, particle size, surface area as well as amount of bio-adsorbent (Ahmad et al., 2006b; Karunarathne and Amarasinghe, 2013; Nor Faizah et al., 2016). It is crucial to select the proper activation technology in order to obtain bio-adsorption with high porosity and surface area that are comparable with commercial adsorbent (Nur Sulihatimarsyila et al., 2017). Bio-adsorbent with surface area between $830 \mathrm{~m}^{2} \mathrm{~g}^{-1}$ and $1300 \mathrm{~m}^{2} \mathrm{~g}^{-1}$ are relatively good and comparable with the commercially activated carbon (Rafatullah et al., 2013). Apart from final polishing, palm-based bio-adsorbent is also applied for POME pre-treatment prior to advanced tertiary systems. The pre-treatment helps to reduce the solids and organic constituents in raw POME, thus avoiding the fouling in the ultra-filtration (UF) system. The pre-treatment is carried out with relatively low

TABLE 4. APPLICATION OF PALM-BASED BIO-ADSORBENT IN POME POLISHING TREATMENT

\begin{tabular}{|c|c|c|c|c|c|c|c|c|c|}
\hline \multirow{2}{*}{$\begin{array}{l}\text { Treatment } \\
\text { System }\end{array}$} & \multicolumn{4}{|c|}{ Bio-adsorbent production } & \multicolumn{4}{|c|}{ Removal efficiency (\%) } & \multirow{2}{*}{ References } \\
\hline & Precursor & $\begin{array}{c}\text { Carbonisation } \\
\text { method }\end{array}$ & $\begin{array}{c}\text { Activation } \\
\text { method }\end{array}$ & $\begin{array}{c}\text { BET } \\
\left(\mathrm{m}^{2} \mathrm{~g}^{-1}\right)\end{array}$ & BOD & COD & Colour & TSS & \\
\hline Batch adsorption & EFB & Pyrolysis & $\mathrm{N}_{2}$ & 937 & 88 & 98 & - & 96 & $\begin{array}{c}\text { Nur Sulihatimarsyila } \\
\text { et al. (2017) }\end{array}$ \\
\hline Batch adsorption & OPKS & Conventional & Steam & 607 & - & 80 & - & - & $\begin{array}{l}\text { Rugayah et al. } \\
\text { (2014) }\end{array}$ \\
\hline Batch adsorption & $\begin{array}{l}\text { Mesocarp } \\
\text { fibre }\end{array}$ & Conventional & Steam & 494 & - & 70 & - & 88 & $\begin{array}{l}\text { Ibrahim et al. } \\
\qquad(2017)\end{array}$ \\
\hline Batch adsorption & OPKS & Microwave & $\mathrm{KOH}$ & 1252 & - & - & 100 & - & $\begin{array}{c}\text { Mohammed } \\
\text { (2013) }\end{array}$ \\
\hline $\begin{array}{l}\mathrm{UF}+\text { column } \\
\text { adsorption }\end{array}$ & OPKS & Conventional & Steam & 566 & - & 75 & 98 & - & $\begin{array}{c}\text { Nor Faizah et al. } \\
\text { (2016) }\end{array}$ \\
\hline $\begin{array}{l}\text { Coagulation- } \\
\text { flocculation + } \\
\text { column } \\
\text { adsorption }\end{array}$ & OPKS & Conventional & Steam & 566 & - & 81 & 97 & - & $\begin{array}{c}\text { Nor Faizah et al. } \\
\text { (2016) }\end{array}$ \\
\hline $\begin{array}{l}\text { Pre-treatment } \\
\text { before UF }\end{array}$ & OPKS & - & Steam & - & 63 & 42 & - & 71 & $\begin{array}{l}\text { Azmi and Yunos } \\
\text { (2014) }\end{array}$ \\
\hline Batch adsorption & EFB & Pyrolysis & Steam & & 886 & Mn and & $\mathrm{H}_{2} \mathrm{~S}$ removal & & Amosa (2015) \\
\hline $\begin{array}{l}\text { Pre-treatment } \\
\text { before algae }\end{array}$ & OPKS & - & - & - & - & 83 & - & 92 & $\begin{array}{l}\text { Takriff et al. } \\
\qquad(2016)\end{array}$ \\
\hline
\end{tabular}

Notes: BOD - biological oxygen demand. COD - chemical oxygen demand. POME - palm oil mill effluent. EFB - empty fruit bunch. OPKS - oil palm kernel shell. TSS - total suspended solids. BET - Brunauer-Emmet-Teller. 


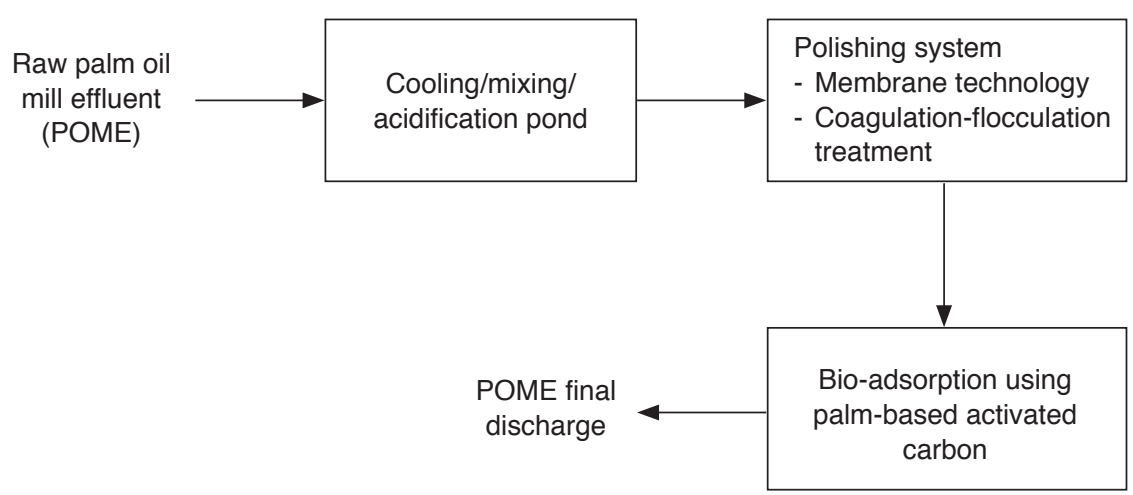

Figure 2. Intergrated polishing treatments using bio-adsorbent for palm oil mill effluent (POME) treatment.

bio-adsorbent dosage (0.2 to $0.6 \mathrm{~g}$ litre $\left.^{-1}\right)$, agitation speed $(20-40 \mathrm{rpm})$ and treatment time $(50 \mathrm{~min})$. Efficient UF coupled with OPKS-AC treatment is capable of removing 90\% pollutant elements from POME (Azmi and Yunos, 2014). In addition, OPKS$\mathrm{AC}$ that is applied on anaerobic treated POME contributes better clarity of effluent, which is suitable for culturing microalgae or other microbes (Takriff et al., 2016). Furthermore, a study also proved that palm-based bio-adsorbent was capable of adsorbing manganese $(\mathrm{Mn})$ and hydrogen sulphide $\left(\mathrm{H}_{2} \mathrm{~S}\right)$ from POME final discharge of ponding system. The concentration levels of $\mathrm{Mn}$ and $\mathrm{H}_{2} \mathrm{~S}$, reduced to 0.136 and 0.061 ppm from 2.14 and $0.6 \mathrm{ppm}$, respectively could serve as recycled water for boiler and cooling tower (Amosa, 2015). In future, bio-adsorbents have great potential for hybrid application with either conventional or innovative POME polishing technology, as demonstrated by other types of adsorbent. The advanced treatments include commercial activated carbon (CAC) hybrid with ultrasound (US) cavitation (Parthasarathy et al., 2016), CAC hybrid with membrane bioreactor, MBR (Damayanti et al., 2011), and CAC combined with magnetic field treatment (Mohammed et al., 2014). Earlier study has found that powdered activated carbon is a good choice for COD removal compared to zeolite and Moringa oliefera, as a biofouling reducer (BFR). BFR enhancement in MBR system reduced fouling rates, operated at higher flux, reduced membrane area, and finally reduced operational cost (Damayanti et al., 2011). While, the novel microbial fuel cell with granular CAC is able to produce POME with a final BOD at $16 \mathrm{mg} \mathrm{litre}^{-1}$, thus meeting the POME final discharge standard limits (Tee et al., 2016). Besides, POME polishing that employs application of CAC adsorption and US cavitation achieved removal efficiencies of almost $100 \%$ COD and TSS as compared to US cavitation alone which removed $79.46 \%$ of COD and $95.83 \%$ of TSS. This observation of US cavitation indicates the degradation of complex organic matter into simpler forms which can be further adsorbed by AC whilst enhancing the overall performance either with improved treatment efficiency or shorter operation time (Parthasarathy et al., 2016). It was believed that the bio-adsorbent not only helps to further remove organic pollutants and colour from POME final discharge, but improves the performance of prevailing polishing system such as UF, MBR and US cavitation system.

\section{CONCLUSION}

As the oil palm industry continues to progress towards a new era, more challenges are anticipated when stringent limit of POME final discharge is imposed by the Malaysia DOE, especially regarding the BOD and colour. Conventional ponding system requires high retention time, maintenance and larger land space. Moreover, the discharged effluents from ponding system are unable to fulfill the new DOE standard effluent discharge limit (BOD $<20 \mathrm{mg}$ litre $^{-1}$ ). Meanwhile, prevailing polishing technologies such as membrane technology and coagulation-flocculation treatment are a major challenge for POME treatment that incurs high capital and operating costs. As a roadmap to palm oil zero-emission, the utilisation of solid waste in mills (EFB and OPKS) as a bio-adsorbent appears to improve the efficiency of existing POME treatment by reducing BOD, COD, colour and TSS and is deemed reliable in achieving consistent final discharge quality. Further efforts should be made to explore the regeneration method on spent bioadsorbents from the treatment system or it can be recycled as soil conditioner, bio-fertiliser or reuse as fuel. The integrated system of conventional and/or advanced POME polishing treatment with palm-based bio-adsorbents could be considered as sustainable approach, thus solving environmental problems of waste disposal and pollution control for the oil palm industry. 


\section{ACKNOWLEDGEMENT}

We would like to thank the Director-General of MPOB for permission to publish this article.

\section{REFERENCES}

ADAM, S; SYED AHMAD, S S N; HAMZAH, N $\mathrm{M}$ and DARUS, N A (2016). Composting of empty fruit bunch treated with palm oil mill effluent and decanter cake. Regional Conference on Science, Technology and Social Sciences (RCSTSS 2014): Science and Technology. Springer Singapore, Singapore. p. 437-445. DOI:10.1007/978-981-10-0534-3-43.

AHMAD, A L; CHONG, M F and BHATIA, S (2006a). Prediction of breakthrough curves for adsorption of complex organic solutes present in palm oil mill effluent (POME) on granular activated carbon. Industrial and Engineering Chemistry Research, 45(20): 6793-6802.

AHMAD, A L; CHONG, M F; BHATIA, $S$ and ISMAIL, S (2006b). Drinking water reclamation from palm oil mill effluent (POME) using membrane technology. Desalination, 191: 35-44. DOI:10.1016/j. desal.2005.06.033.

AHMAD, A L; SUMATHI, S and HAMEED, B H (2006c). Coagulation of residue oil and suspended solid in palm oil mill effluent by chitosan, alum and PAC. Chem. Eng. J. 118: 99-105. http:// dx.doi. org/10.1016/j.cej.2006.02.001

AHMAD, A L; ISMAIL, S and BHATIA, S (2003a). Water recycling from palm oil mill effluent (POME) using membrane technology. Desalination, 157: 87-95.

AHMAD, A L; SUZYLAWATI, I; NORLIZA, I and SUBHASH, B (2003b). Removal of suspended solid and residual oil from palm oil mill effluent. J. Chem. Tech. Biotech., 78: 971-978.

AHMED, Y; YAAKOB, Z; AKHTAR, P and SOPIAN, $K$ (2015). Production of biogas and performance evaluation of existing treatment processes in palm oil mill effluent (POME). Renew. Sustain. Energy Rev., 42: 1260-1278. http://dx.doi.org/10.1016/j. rser.2014.10.073

AHMED, M J and THEYDAN, S K (2014). Fluoroquinolones antibiotics adsorption onto micro- porous activated carbon from lignocellulosic biomass by microwave pyrolysis. J. Taiwan Inst. Chem. Eng., 45: 219-26.

ALHAJI, M H; SANAULLAH, K; LIM, S F; KHAN, A; HIPOLITO, C N; ABDULLAH, M O; BHAWANI,
S A and JAMIL, T (2016). Photocatalytic treatment technology for palm oil mill effluent (POME) - a review. Process Saf. Environ. Prot., 102: 673-686.

AMAT, A N A; TAN, Y H; LAU, W J; LAI, G S; ONG C S; MOKHTAR, N M; SANI, N A A; ISMAIL, A F; GOH, P S; CHONG, K C and LAI, S O (2015). Tackling colour issue of anaerobically-treated palm oil mill effluent using membrane technology. J. Water Process Eng., 8: 221-226.

AMOSA, M K (2015). Environmental nanotechnology, monitoring \& management process optimization of $\mathrm{Mn}$ and $\mathrm{H}_{2} \mathrm{~S}$ removals from POME using an enhanced empty fruit bunch (EFB)based adsorbent produced by pyrolysis. Environ. Nanotechnology, Monit. Manag., 4: 93-105.

ANG, W L; MOHAMMAD, A W; BENAMOR, A and HILAL, N (2016). Chitosan as natural coagulant in hybrid coagulation-nanofiltration membrane process for water treatment. J. Environ. Chem. Eng., 4: 4857-4862.

ASADULLAH and RATHNASIRI, P G (2015). Optimization of adsorption-coagulation process for treatment of palm oil mill effluent (pome) using alternative coagulant. International Research Symposium on Engineering Advancements 2015 (RSEA 2015). SAITM, Malabe, Sri Lanka. Malabe. p. 68-71.

AZMI, N A; YUNOS, M and ZAKARIA, R (2012). Application of sandwich membrane for the treatment of palm oil mill effluent (POME) for water reuse. Proced. Eng., 44: 1980-1981.

AZMI, N S and YUNOS, K F M (2014). Wastewater treatment of palm oil mill effluent (POME) by ultrafiltration membrane separation technique coupled with adsorption treatment as pre-treatment. Agriculture and Agricultural Science Procedia, 2: 257264.

BABEL, $S$ and KURNIAWAN, T A (2004). Cr (VI) removal from synthetic wastewater using coconut shell charcoal and commercial activated carbon modified with oxidizing agents and/or chitosan. J. Chemosphere, 54: 951-967. DOI:10.1016/j. chemosphere.2003.10.001.

BACHMANN, R T and LOH, S K (2013). Oil Palm biomass waste utilization - potential and challenges. Proc. of the PIPOC 2013 International Palm Oil Congress - Chemistry, Processing Technology and Bio-energy Conference. MPOB, Bangi. p. 35-36.

BELLO, M M; NOROUZI, M M; ABAH, L C; CHOONG, T S Y; KOAY, Y $S$ and KESHANI, $S$ (2013). POME is treated for removal of color from 
biologically treated POME in fixed bed column: applying wavelet neural network (WNN). J. Hazard. Mater., 262: 106-113.

BELLO, M M; NOUROUZI, M M and ABDULLAH, L C (2014). Tertiary treatment of biologically treated POME in fixed-bed column: color and COD removal. Adv. Environ. Biol,. 8: 565-571.

BELLO, M M and ABDUL RAMAN, A A (2017). Trend and current practices of palm oil mill effluent polishing: application of advanced oxidation processes and their future perspectives. J. Environ. Manage.,198: 170-182.

BHATIA, S; OTHMAN, Z and AHMAD, A L (2007). Coagulation-flocculation process for POME treatment using Moringa oleifera seeds extract: optimization studies. Chem. Eng. J., 133: 205-212.

CHIN, K (2016). Malaysia biomass industries review, opportunities \& challenges. Proc. of the POMREQ 2016 National Seminar on Palm Oil Milling, Refinery, Environment and Quality. The Royal Chulan Hotel, Kuala Lumpur. p. 33-34.

CHIN, K K; LEE, S W and MOHAMMAD, H H (1996). A study of palm oil mill effluent treatment using a pond system. Water Sci. Technol., 34: 119-123. DOI:10.1016/j.cej.2012.12.038.

CHIN, M J; POH, P E; YEY, B T; CHAN, E S and CHIN, K L (2013). Biogas from palm oil mill effluent (POME): opportunities and challenges from Malaysia's perspective. Renew Sustain Energy Rev., 26: 717-726.

DAMAYANTI, A; UJANG, Z and SALIM, M R (2011). Bioresource technology the influenced of PAC, zeolite, and Moringa oleifera as biofouling reducer (BFR) on hybrid membrane bioreactor of palm oil mill effluent (POME). Bioresour. Technol., 102: 4341-4346. DOI:10.1016/j.biortech.2010.12.061.

DEPARTMENT OF ENVIRONMENT (DOE) (2015). Deraf Peraturan-peraturan Kualiti Alam Sekeliling (Kilang Minyak Sawit Mentah). http:// www.doe.gov.my/portal_services/wp-content/ uploads / 2015/07/Versi-BM-Peraturan-KKSJulai-2015.pdf., accessed on 18 September 2017.

DEPARTMENT OF ENVIRONMENT (DOE) (1982). Environment Quality Act 1974-Environment Quality (Prescribed Premises)(Crude Palm Oil) (Amendment) Regulations 1982. https://www.doe. gov.my / portalv1/wpcontent/uploads/2015/01/ Environmental_Quality_Prescribed_Premises_ Crude_Palm_Oil_Amendment_Regulations_1982__P.U.A_183-82.pdf.
EVBUOMWAN, B O; ABUTU, A S and EZEH, C P (2012). The effects of carbonization temperature on some physicochemical properties of bamboo based activated carbon by potassium hydroxide $(\mathrm{KOH})$ activation. Greener J. Physical Sciences, 3(5): 187-191.

FOO, K Y and AMEED, B H (2011a). Microwaveassisted preparation of oil palm fiber activated carbon for methylene blue adsorption. Chem. Eng. J., 166: 792-795. DOI:10.1016/j.cej.2010.11.019.

FOO, K Y and HAMEED, B H (2011b). Preparation of oil palm (Elaeis) empty fruit bunch activated carbon by microwave-assisted $\mathrm{KOH}$ activation for the adsorption of methylene blue. Desalination, 275: 302-305. DOI:10.1016/j.desal.2011.03.024.

GANIYU, S O; VAN HULLEBUSCH, E D; CRETIN, M; ESPOSITO, G and OTURAN, M A (2015). Coupling of membrane filtration and advanced oxidation processes for removal of pharmaceutical residues: a critical review. Sep. Purif. Technol., 156: 891-914.

GUO, J; GUI, B; XIANG, S; BAO, X; ZHANG, $\mathrm{H}$ and LUA, A C (2008). Preparation of activated carbons by utilizing solid wastes from palm oil processing mills. J. Porous Mater., 15: 535-540. DOI:10.1007/ s10934-007-9129-z.

HOSSAIN, M A; JEWARATNAM, J and GANESAN, P (2016). Prospect of hydrogen production from oil palm biomass by thermochemical process - a review. Int. J. Hydrogen Energy, 41: 16637-16655.

IBRAHIM, I; HASSAN, M A; SURAINI, A A; SHIRAI, Y; ANDOU, Y; OTHMAN, M R; MOHD ALI, A A and ZAKARIA, M R (2017). Reduction of residual pollutants from biologically treated palm oil mill ef fluent final discharge by steam activated bioadsorbent from oil palm biomass. J. Clean. Prod., 141: 122-127. DOI:10.1016/j.jclepro.2016.09.066.

IDRIS, M A; JAMI, M S and MUYIBI, S A (2010). Tertiary treatment of biologically treated palm oil mill effluent (POME) using UF membrane system: effect of MWCO and transmembrane pressure. Int. J. Chem. Environ. Eng., 1: 108-112.

JEGATHEESAN, V; PRAMANIK, B K; CHEN, J; NAVARATNA, D; CHANG, C Y and SHU, L (2016). Treatment of textile wastewater with membrane bioreactor: a critical review. Bioresour. Technol., 204: 202-212.

JOSEPH, C G; BONO, A; KRISHNAIAH, D; CHOW, Y L and NG, C B (2009). Morphology and sorption kinetic studies on L-type activated carbons prepared from oil palm shells by $\mathrm{ZnCl}_{2}$ and $\mathrm{H}_{3} \mathrm{PO}_{4}$ activation. J. Appl. Sci., 9: 3131-3135. 
JULAIDI, R (2014). Regulatory requirements for biogas plants, effluent discharge and flue gas emissions for palm oil mill. Paper presented at the Seminar on Palm Oil Mill, Refinery, Environmental and Quality. Pullman Hotel, Kuching, Sarawak, Malaysia. 4 October 2014.

KARUNARATHNE, H D S S and AMARASINGHE, B M W P K (2013). Fixed bed adsorption column studies for the removal of aqueous phenol from activated carbon prepared from sugarcane bagasse. Energy Procedia, 34: 83-90. DOI:10.1016/j. egypro.2013.06.736.

KEELEY, J; SMITH, A D; JUDD, S J and JARVIS, $P$ (2014). Reuse of recovered coagulants in water treatment: an investigation on the effect coagulant purity has on treatment performance. Sep. Purif. Technol., 131: 69-78.

KRISHNAN, Y; BONG, C P C; AZMAN, N F; ZAKARIA, Z; OTHMAN, N; ABDULLAH, N; HO, C S; LEE, C T; HANSEN, S B and HARA, H (2017). Co-composting of palm empty fruit bunch and palm oil mill effluent: microbial diversity and potential mitigation of greenhouse gas emission. J. Clean. Prod., 146: 94-100. DOI:10.1016/j.jclepro.2016.08.118.

KUSHAIRI, A (2017). Malaysian oil palm industry performance 2016 and prospects for 2017. Paper presented at the Palm Oil Economic Review and Outlook Seminar. Pullman Kuala Lumpur City Centre, Kuala Lumpur.

LEES, E J; NOBLE, B; HEWITT, R and PARSONS, $S$ A (2001). The impact of residual coagulant on the respiration rate and sludge characteristics of an activated microbial biomass. Process Saf. Environ. Prot., 79: 283-290.

LIEW, W; KASSIM, M; MUDA, K; LOH, S K and AFFAM, A (2015). Conventional methods and emerging wastewater polishing technologies for palm oil mill effluent treatment: a review. J. Environ. Manage., 14: 222-235.

LOH, S K and CHOO, Y M (2013). Prospect, challenges and opportunities on biofuels in Malaysia. Advances in Biofuels (Pogaku, R and Sarbatly, R eds.). Springer, Boston, MA. p. 3-14.

LOH, S K; LAI, M E; MUZZAMMIL, N; LIM, W S and CHOO, Y M (2013). Zero discharge treatment technology of palm oil mill effluent. J. Oil Palm Res. Vol. 25: 273-281.

LOH, S K; NASRIN, A B; MOHAMAD AZRI, S; NURUL ADELA, B; MUZZAMMIL, N; DARYL JAY, T; STASHA ELEANOR, R A; LIM, W S; CHOO, Y
M and KALTSCHMITT, M (2017). First report on Malaysia's experiences and development in biogas capture and utilization from palm oil mill effluent under the Economic Transformation Programme: current and future perspectives. Renew. Sustain. Energy Rev., 74: 1257-1274. DOI:10.1016/j.rser. 2017.02.066.

MPOB (2016). http:// bepi.mpob.gov.my/index. $\mathrm{php} / \mathrm{en} /$ statistics / production / 168-production2016/746-production-of-crude-oil-palm-2016.html

MPOB (2017). Chapter 9: Deepening Malaysia's palm oil advantage. http://www.mpob.gov.my/ images / stories / pdf/NKEA-Chapter_9_Palm_Oil. pdf., accessed on 15 September 2017.

MA, A N (1999). Treatment of palm oil mill effluent. Oil Palm and the Environment. A Malaysian Perspective (Singh, G; Huan, L K; Teo, L and David, L K eds.). Malaysian Oil Palm Growers' Council, Malaysia. p. 113-123.

MALIK, P K (2003). Use of activated carbons prepared from sawdust and rice-husk for adsorption of acid dyes: a case study of Acid Yellow 36. Dye. Pigment., 56: 239-249. DOI.org/10.1016/S01437208(02)00159-6.

MALAKAHMAD, A and CHUAN, S Y (2013). Application of response surface methodology to optimize coagulation-flocculation treatment of anaerobically digested palm oil mill effluent using alum. Desalin. Water Treat. 51: 6729-6735. http:// dx.doi.org/ 10.1080/19443994.2013.791778

MOHAMMED, R R (2013). Decolorisation of biologically treated palm oil mill effluent (POME) using adsorption technique. Int. Ref. J. Eng. Sci., 2: 1-11.

MOHAMMED, R R and FONG, M (2014). Treatment and decolorization of biologically treated palm oil mill effluent (POME) using banana peel as novel biosorbent. J. Environ. Manag., 132: 237-249.

MOHAMMED, R R; KETANCHI, R M and MCKAY, $G$ (2014). Combined magnetic field and adsorption process for treatment of biologically treated palm oil mill effluent (POME). Chem. Eng. J., 243: 31-42. DOI:10.1016/j.cej.2013.12.084.

NAHRUL HAYAWIN, Z; ASTIMAR, A A; MOHD HAKIMI, I; ABDUL KHALIL, H P S; BIDATTUL SYIRAT, Z and MENON, N R (2014). The growth and reproduction of Eisenia Eugeniae in mixtures of empty fruit bunch and palm oil mill effluent. Compost Science \& Utilization, 22: 40-46.

NAHRUL HAYAWIN, Z; ASTIMAR, A A; NUR RASHYEDA, R; NOR FAIZAH, J; IDRIS, J; RAVI 
MENON, N; BIDATTUL SYIRAT, Z; ROPANDI, $\mathrm{M}$ and ANAFIAH HAMZAH (2016a). Influence of frond, stem and roots of oil palm seedlings in vermicompost from oil palm biomass. J. Oil Palm Res. Vol. 28 (4): 479-484.

NAHRUL HAYAWIN, Z; ASTIMAR, A A; JUFERI, I; ROPANDI, M; HASSAN, M A; EZYANA, K B and SURAINI, A A (2016b). Microwave-assisted precarbonisation of palm kernel shell produced charcoal with high heating value and low gaseous emission. J. Clean. Prod., 142(4): 2945-2949. DOI:10.1016/j. jclepro.2016.10.176.

NAHRUL HAYAWIN, Z; JUFERI, I; SURAINI, A A; MOHD ALI, H; ASTIMAR, A A and ROPANDI, M (2016c). Bio-coal production from oil palm biomass using a self-sustained carbonisation system. $M P O B$ Information Series No. 726. http://palmoilis.mpob. gov.my/publications / TOT/TT597.pdf

NATIONAL INNOVATION AGENCY OF MALAYSIA (2013). National Biomass Strategy 2020: New Wealth Creation for Malaysia's Palm Oil Industry, Version 2. Accessed on 19 October 2016.

NASRULLAH, M; SINGH, L; MOHAMAD, Z; NORSITA, S; KRISHNAN, S; WAHIDA, $\mathrm{N}$ and ZULARISAM, A W (2017). Treatment of palm oil mill effluent by electrocoagulation with presence of hydrogen peroxide as oxidizing agent and polialuminum chloride as coagulant-aid. Water Resources and Industry, 17: 7-10.

NOR FAIZAH, J; ASTIMAR, A A; NOORSHAMSIANA, A W; WAN HASAMUDIN, W $\mathrm{H}$ and NAHRUL HAYAWIN, Z (2016). Application of palm kernel shell activated carbon for the removal of pollutant and color in palm oil mill effluent treatment. J. Earth, Environ. Heal. Sci., 2: 15-20. DOI:10.4103/2423-7752.181802.

NOURANI, M; BAGHDADI, M; JAVAN, M and BIDHENDI, G N (2016). Production of a biodegradable flocculant from cotton and evaluation of its performance in coagulation-flocculation of kaolin clay suspension: optimization through response surface methodology (RSM). J. Environ. Chem. Eng., 4: 1996 - 2003.

NURLIYANA, M Y; H'NG, P S; RASMINA, H; UMI KALSOM, M S; CHIN, K L; LEE, S H; LUM, W $\mathrm{C}$ and KHOO, G D (2015). Effect of $\mathrm{C} / \mathrm{N}$ ratio in methane productivity and biodegradability during facultative co-digestion of palm oil mill effluent and empty fruit bunch. Industrial Crops and Products, 76: $409-415$.

NUR SULIHATIMARSYILA, A W; LAU, H L N; LOH, S K; ASTIMAR, A A; ZULKIFLI, A R and
CHOO, Y M (2017). Activated carbon from oil palm biomass as potential adsorbent for palm oil mill effluent treatment. J. Oil Palm Res.Vol. 29: 278-290.

OTHMAN, M R; HASSAN, M A; SHIRAI, Y; BAHARUDIN, A S; MOHD ALI, A A and IDRIS, J (2014). Treatment of effluents from palm oil mill process to achieve river water quality for reuse as recycled water in a zero emission system. J. Clean. Prod., 67: 58 - 61. DOI:10.1016/j.jclepro.2013.12.004.

PARTHASARATHY, $S$; MOHAMMED, R R; CHONG, M F; GOMES, R L and MANICKAM, S (2016). A novel hybrid approach of activated carbon and ultrasound cavitation for the intensification of palm oil mill effluent (POME) polishing. J. Clean. Prod., 112: 1218-1226. DOI:10.1016/j. jclepro.2015.05.125.

POH, P E and CHONG, M F (2009). Development of anaerobic digestion methods for palm oil mill effluent (POME) treatment. Bioresource Technology, 100: $1-9$.

POH, P E; ONG, W Y J; LAU, E V and CHONG, M $N$ (2014). Investigation on micro-bubble flotation and coagulation for the treatment of anaerobically treated palm oil mill effluent (POME). J. Environ. Chem. Eng., 2: 1174-1181.

RAFATULLAH, M; AHMAD, T; GHAZALI, A; SULAIMAN, O; DANISH, $\mathrm{M}$ and HASHIM, R (2013). Critical reviews in environmental science and technology oil palm biomass as a precursor of activated carbons: a review oil palm biomass as a precursor of activated carbons: a review. Environ. Sci. Technol., 43: 1117-1161. DOI:10.1080/10934529.2 011.627039 .

RASHED, M N (2013). Adsorption technique for the removal of organic pollutants from water and wastewater. Organic Pollutant - Monitoring, Risk and Treatment (Rashed, M N ed.). InTech, Rijeka. p. 167-194.

RUGAYAH, A F; ASTIMAR, A A and NORZITA, N (2014). Preparation and characterisation of activated carbon from palm kernel shell by physical activation with steam. J. Oil Palm Res. Vol. 26: 251-264.

SAEED, M O; AZIZLI, $\mathrm{K}$ A M; ISA, $\mathrm{M} \mathrm{H}$ and EZECHI, E H (2016). Treatment of POME using Fenton oxidation process: removal efficiency, optimization, and acidity condition. Desalin. Water Treat., 3994: 1-10.

SAID, M; AHMAD, A; MOHAMMAD, AW; NOR, M $\mathrm{T} \mathrm{M}$ and SHEIKH ABDULLAH, S R (2015). Blocking mechanism of PES membrane during ultrafiltration of POME. J. Ind. Eng. Chem., 21: 182 - 188. 
SHAK, K P Y and WU, T Y (2014). Coagulationflocculation treatment of high-strength agroindustrial wastewater using natural Cassia obtusifolia seed gum: treatment efficiencies and flocs characterization. Chem. Eng. J., 256: 293 - 305.

SITI HADJAR, M A; ASTIMAR, A A; NORZITA, N and NORAISHAH, S A (2012). Phenol adsorption by activated carbon of different fibre size derived from empty fruit bunches. J. Oil Palm Res. Vol. 24: 15241532.

SHAVANDI, M A; HADDADIAN, Z; ISMAIL, M H S; ABDULLAH, N and ABIDIN, Z Z (2012). Removal of residual oils from palm oil mill effluent by adsorption on natural zeolite. Water. Air. Soil Pollut., 223: 4017-4027. http:/ / dx.doi.org/10.1007/ 11270-012-1169-6

TABASSUM, S; ZHANG, Y and ZHANG, Z (2015). An integrated method for palm oil mill effluent (POME) treatment for achieving zero liquid discharge - a pilot study. J. Clean. Prod., 95: 148-155.

TAHA, M R and IBRAHIM, A H (2014). COD removal from anaerobically treated palm oil mill effluent (AT-POME) via aerated heterogeneous Fenton process: optimization study. J. Water Process Eng., 1: 8-16.

TAHERAN, $\mathrm{M}$; BRAR, $\mathrm{S}$ K; VERMA, $\mathrm{M}$; SURAMPALLI, R Y; ZHANG, T C and VALERO, J R (2016). Membrane processes for removal of pharmaceutically active compounds (PhACs) from water and wastewaters. Sci. Total Environ., 547: 60 - 77.

TAKRIFF, M S; ZAKARIA, M Z; SAJAB, M S and TEOW, Y H (2016). Pre-treatments anaerobic palm oil mill effluent (POME) for microalgae treatment. Indian J. Sci. Technol., 9(21): 1-8. DOI:10.17485/ ijst/2016/v9i21/95248.

TAN, Y H; GOHA, P S; LAI, G S; LAU, W J and ISMAIL, A F (2014). Treatment of aerobic treated palm oil mill effluent (AT-POME) by using $\mathrm{TiO}_{2}$ photocatalytic process. J. Teknol. Sci. Eng., 70: 61-63. http:/ / dx.doi.org/10.11113/jt.v70.3436

TEE, P; OMAR, M; AI, I; TAN, W; AFIZAL, M; AMIN, M; NOLASCO-HIPOLITO, C and BUJANG,
K (2016). Performance evaluation of a hybrid system for efficient palm oil mill effluent treatment via an air-cathode, tubular upflow microbial fuel cell coupled with a granular activated carbon adsorption. Bioresour. Technol., 216: 478 - 485. DOI:10.1016/j. biortech.2016.05.112.

THEO, W L; LIM, J S; HO, W S; HASHIM, H; LEE, C T and MUIS, Z A (2017). Optimisation of oil palm biomass and palm oil mill effluent (POME) utilisation pathway for palm oil mill cluster with consideration of BioCNG distribution network. Energy, 121: 865-883.

VIJAYARAGHAVA, K; AHMAD, D and AZIZ, M E A (2007). Aerobic treatment of palm oil mill effluent. J. Environ. Manage., 82: 24-31.

WAN DAUD, $W \mathrm{M}$ A; WAN ALI, $\mathrm{W} S$ and SULAIMAN, MZ (2000). The effects of carbonization temperature on pore development in palm-shellbased activated carbon. Carbon, 38: 1925-1932.

WU, T Y; MOHAMMAD, A W; JAHIM, J and ANUAR, N (2009). A holistic approach to managing palm oil mill effluent (POME): biotechnological advances in the sustainable reuse of POME. Biotechnol. Adv., 27: 40-52.

WU, T Y; MOHAMMED, A W; JAHIM, J M and ANUAR, N (2010). Pollution control technologies for the treatment of palm oil mill effluent (POME) through end-of-pipe processes. J. Environ. Manag., 91: $1467-1490$

YOSHIZAKI, T; SHIRAI, Y; HASSAN, M A; BAHARUDDIN, A S; ABDULLAH, N M R; SULAIMAN, A and BUSU, Z (2012). Economic analysis of biogas and compost projects in a palm oil mill with clean development mechanism in Malaysia. Environ. Dev. Sustain., 14: 1065 - 1079. DOI:10.1007 / s10668-012-9371-7.

ZAHRIM, A Y; NASIMAH, A and HILAL, N (2014). Pollutants analysis during conventional palm oil mill effluent (POME) ponding system and decolourisation of anaerobically treated POME via calcium lactate-polyacrylamide. J. Water Process Eng., 4: 159-165. 